\title{
Affordances of Digital Archives: The Case of the Prozhito Archive of Personal Diaries
}

\author{
Ekaterina Kalinina
}

\subsection{INTRODUCTION}

Despite being the guardians of public records Russian archives not always grant the right of public accessibility (TASS 2018; Rambler 2017; Komissiâ 2016; Slobodenyuk 2019). Not being able to get access to archival materials, professional historians and amateurs alike have to look for alternative ways of getting hold of historical sources, and in such a situation digital databases can become their salvation (Venyavkin 2017).

Today, one can get access to a wide range of historical documents online: project Ustnầ istoriâ (Oral history) makes recorded talks with famous intellectuals accessible through a web platform (http://oralhistory.ru); project Prozhito digitizes and publishes personal diaries (http://prozhito.org); database Otkrytyj spisok (Open list) makes it possible to find information about persons who fell victim to the Soviet repression machine (http://ru.openlist. wiki); photo databases such as Pastvu (http://pastvu.com) and Istoriâ Rossii v fotografiâh (History of Russia in photographs, http://russianphoto.ru) grant access to a wide range of photo materials.

These and other similar initiatives carry a promise of wider access to historical sources. Scholars even stress that digital archives form "public alternatives to official constructions of the past and ways in which that past is to be studied" (Lapina-Kratasyuk and Rubleva 2018, 164; Garde-Hansen et al. 2009). Alexandra Herlitz and Jonathan Westin $(2018,451)$ believe that "[c]onflating

E. Kalinina $(\bowtie)$

Jönköping University, Jönköping, Sweden

e-mail: ekaterina.kalinina@ju.se 
different archives digitally makes the archival substance less vulnerable to any agenda of an archiving individual and may therefore lead to a greater objectivity and reliability of the accumulated material." In Russia such digital platforms become essential players in political, social and cultural life by allowing people to learn about the past from other sources rather than those that are state approved. This means that digital archives have the potential to not only challenge established historical discourses but also question the leading role of the state in the production of historical narratives.

This idea about the democratizing potential of digital archives is rooted in the belief that digital technologies are the solution to many problems. Recent studies of digital media, however, show that scholars should be more careful when stressing the democratic potential of the web, as internet is not necessarily democracy's magical solution (Fuchs 2017; Morozov 2011; Nisbet et al. 2012; Rød and Weidmann 2015; Stoycheff et al. 2016). When archival collections become digital, various legal constraints and the fragmentary nature of archival records might lead to the reproduction of already existing biases. So, while some scholars (Herlitz and Westin 2018) see digital archiving as a possibility to safeguard and disseminate data to wider publics, others (Aghostino 2016; Azoulay 2012) insist on a more critical approach to digital archives by arguing that the non-neutral and ideological nature of digital infrastructures predetermines what type of content becomes visible and how much visibility it gets. Hence, in order to study the potential of digital archives for the democratization of history, one should look at what users can and cannot do in order to create new narratives that can disrupt dominant discourses of power.

Therefore, the aim of this chapter is to study affordances of digital archives, that is, the properties that allow users to perform certain actions on the platforms, in order to explore their democratic potential. To be able to do that, affordance analysis, which allows one to investigate the technological and organizational structures of digital platforms, the amount and quality of data available, the social underpinnings entangled in technologies and the degree of user participation, is applied to the Russian digital archive of diaries Prozhito.

The research questions that guide this chapter are: what kind of data is (not) available in the archive and why? What information about affordances is available and what does it tell us about the composition, constraints, limitations and affordances of the archive? How much participation does the archive allow? What kind of participation does the archive support? These questions are addressed by focusing on Prozhito as an environment that allows certain actions and forms of participation, rather than on specific uses of Prozhito. This means that this study is not a reception study but rather a research of digital archives as media environments.

In order to address the above-mentioned scholarly interest, the chapter starts with a section outlining the theoretical framework and methodological guidelines, followed by the analysis of Prozbito and a brief conclusion summarizing major findings. 


\subsection{Theoretical Tools for Unpacking Archives}

Some scholars believe that archives play an important role in the formation of national consciousness and in the development of democratic liberal citizenship, because they preserve evidence which is paramount for the work of justice and crucial for keeping individuals, groups and institutions accountable (Joyce 1999). Jacques Derrida, for example, claims the centrality of the archive to the existence of democratic society by stating that "[e]ffective democratization can always be measured by this essential criterion: the participation in and access to the archive, its constitution, and its interpretation" (Derrida 1995, 4).

Scholars also point out that archives are hardly neutral collections of records but rather environments where both technical and organizational structures produce as much as record events (Derrida 1995, 17) and organize data in a way that might "lead later investigators in a particular direction" (Manoff $2004,16)$. Gillian Rose $(2012,228)$ argues that archives "have effects on what is stored within them" and on "those who use them." Jaimie Baron (2014, 109ff) calls this process archive effect and explains it as a human response toward archival material, which can be triggered by the engagement of a person with archival documents and even purposefully employed to activate the public.

As archives are environments with specific technological and organizational structures the users come in contact with, the concept of affordances could be applied in order to study archival properties and what users can and cannot do with them.

The term "affordance" was first coined by psychologist James J. Gibson in his seminal book The Ecological Approach to Visual Perception (1979) to describe the properties of the environment. Gibson explains affordances as interconnected action possibilities offered by the environment to the subject. He says: "an affordance is not bestowed upon an object by a need of an observer and his act of perceiving it. The object offers what it does because of what it is" (Gibson 1979, 139). In other words, an affordance is the possibility of an action available in the environment that is independent of the subject's ability to perceive this possibility. At the same time an affordance exists relative to action capabilities of the subject. This means that an affordance of an environment might exist, but it only can be activated if the subject has the capacity for an action.

At the same time what a subject perceives about affordances depends much on the information he/she has about them. Depending on the presence or absence of affordances, and the presence and absence of information about them, one can divide affordances into the following types (Gaver 1991): perceptible affordances (both information and action exist), false affordances (information about the affordance might exist but the affordance itself is absent), hidden affordances (affordance exists but information is hidden), and correct rejection (absence of information and affordance) (Gaver 1991). 
Gibson (1979) also suggests two types of affordances: positive and negative, where positive affordances stand for properties that allow certain actions and negative affordances for properties that do not allow certain actions. They can also be called platform constraints. In this text the term "platform constraints" rather than "negative affordances" will be used. Constraints will be divided into technological, legal and ethical constraints in order to cover the whole spectrum of systematic issues.

One has to keep in mind that environments can be characterized by multiple affordances that exist in relation to each other. The notion of nesting helps to conceptualize these relationships between different affordances of environments by suggesting some sort of hierarchy between them. Turner (2005) suggests dividing affordances into simple affordances, that is, usabilities of the environment or objects, and complex affordances, that is, properties of the environment that have an important cultural or historical significance when being used. Meanwhile, Wagman et al. (2016) suggest calling them subordinate and superordinate affordances, pointing to the connections between affordances of different levels: affordances at lower levels have means which allow higher level affordances to come into existence.

In order to trace the relationships between different levels of affordances, Gaver (1991, 82) suggests dividing affordances into sequential and nested, where the former emerge as a result of actions on perceptible affordances (Gaver 1991, 82) while the latter refer to affordances that serve as a context for other affordances. The best example for sequential affordances can be the functions that a user learns about when logged in as an editor or a page administrator. In such case, each affordance that emerges after logging in would be a sequential affordance. Nested affordances are actualized in temporal sequences as well, "yet time is not the sole basis for the nesting of affordances" as "nesting can also exist across levels that differ in order" (Wagman et al. 2016, 2).

Studying affordances is essential for understanding archival composition, which is in turn pivotal for comprehending why some documents are included while others are excluded or censored. Archival composition reflects biases of an archivist and/or donor, providing substantial information about societal, political and cultural contexts of the archives and in turn can shed light on degrees of participation in a given society.

Two key principles of archival practices — provenance and authenticity - help to unpack the composition of archives. In archival studies, while "provenance refers to the documentation of the origins and history of an archived item, authenticity denotes the preservation of the original object rather than the truth or accuracy of its content" (Kallinikos et al. 2013, 361). Both principles are important when it comes to the discussion of an archive's possibility to evoke multi-vocal narratives. As historian Jane Stevenson $(2013,160 ; 170)$ puts it, archives hardly ever store enough material to fully reconstruct the whole life of a person; therefore, it is crucial to know the origins of the available documents as well as their history to be able to construct narratives that would give the fullest picture of the subject in question. 
The principles of provenance and authenticity are challenged in the digital environment because it is difficult to trace the origins of the documents (Marton 2010). This difficulty arises when one gets into contact with digital copies, which usually have neither traces of materiality nor records about their inquisition. In other words, this difficulty is a result of the technological and organizational constraints (negative affordances) of the modern digital platforms that collect and make available historical documents.

\subsection{Methodological Framework and Steps to Unpack PROZHITO ARChIVE}

In order to learn what affordances an environment can offer, one has to engage with this environment. Activity theory, for example, postulates that environments can only be perceived through acting (Albrechtsen 2001). When acted upon, an environment reveals its hidden structures and its constraints as well as what are called perceived and actual affordances, where the first type stands for what a subject thinks he/she can do and the second for what a subject can actually do with/in the given environment (Norman 1988). Hence, in order to learn about affordances of digital archives, one has to try them out.

Taking off from the activity theory, Turner's simple and complex affordances (2005) and Gibson's (1979) positive affordances and constraints, the project investigates what actions are allowed and not allowed on Prozhito. First, the user interface was browsed to collect as much information as possible about the perceived and simple affordances of the platform. Second, the platform was tested in order to create a historical narrative. Preparing for the publication of a special issue of the journal Baltic Worlds dedicated to the Centenary of the Russian Revolution, the author of the chapter has used Prozbito to tell a story about the Russian Revolution from the perspective of its contemporaries. In order to do that diaries tagged with the year 1917 were selected for the analysis and publication (Kalinina and Kochergan 2018). To be able to speak about volunteer experiences, the author joined the community of one of the laboratories as well as followed some of the laboratories online. The choice of the type of participation was defined by the author's experiences and capabilities. Next, in order to learn more about the archival composition of Prozhito, the author interviewed the founders of the project Mikhail Melnichenko (2017) and Ilya Venyavkin (2017) as the information on the website was not sufficient despite a very encompassing description in the section "About the project" $(O$ proekte -in Russian).

\subsection{Unpacking Prozhito}

Prozhito was founded in 2015 by a professional historian, Melnichenko, and his colleagues in order to collect and make available already published diaries and manuscripts. In 2019 Prozhito received the status of Research Institute of 
Ego-documents at the European University in St. Petersburg, Russia, with a whole range of responsibilities, such as the collection and research of egodocuments and the organization of events and laboratories. In September 2019, Prozbito was accepted into the European Ego-Documents Archives and Collections Network (http://prozhito.org) and became recognized by other memory institutions as a legible member (Fig. 21.1).

At the moment of writing, around 1700 diaries are uploaded into the system, with 350 published for the first time. In total, the archive contains 460,000 daily entries. The diaries available in the archive fall into the following categories: (1) transcribed manuscripts found in the archives; (2) transcribed manuscripts donated by the authors or their relatives; 3 ) digitized published diaries and (4) published diaries available online (Interview with Melnichenko 2017).

As a historical source, diaries have their specificity. A diary is usually a notebook filled with handwritten notes arranged by date, which makes it an important historical source that allows one to date events. Entries reporting on everyday occurrences, reflections, emotional experiences and impressions are usually written down for the author's own use, and not with the intention of being published (Fig. 21.2).

Nevertheless, many authors are aware that their diaries can be read by others and even edit them to fit the public eye. While some intentionally write for profit or self-vindication with a possible reading public in mind, others develop secrete coding systems in order to conceal information from the eyes of unwanted readers (Interview with Melnichenko 2017). Compared with memoirs diaries contain less "strategic lies"-intentional misrepresentations of events done with the aim of creating a more favorable self-representation (Interview with Melnichenko 2017). Still, using diaries as a historical source

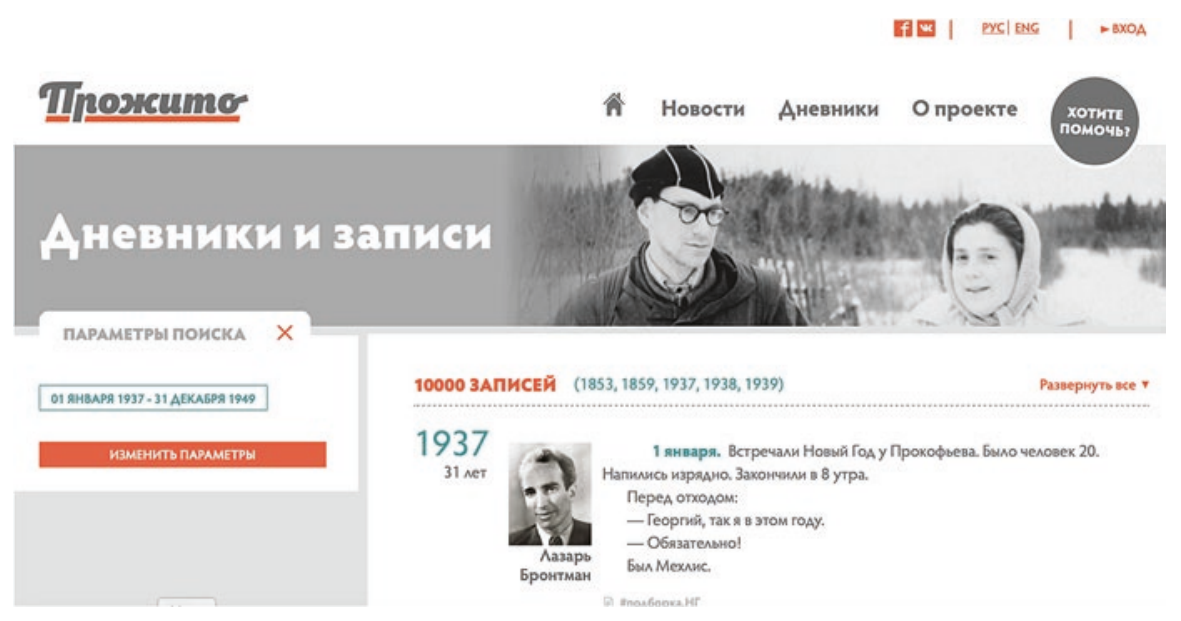

Fig. 21.1 Prozhito. User interface 


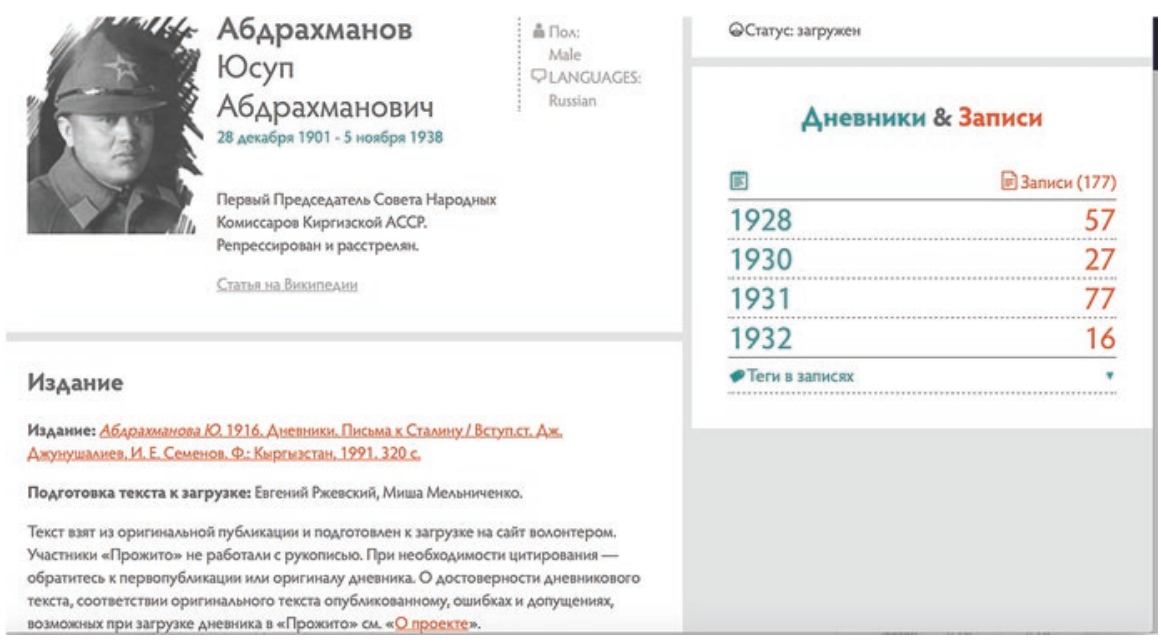

Fig. 21.2 Prozhito. Author page

requires critical reflection on the part of the reader. One has to understand that the spectrum of motivations of the author, who keeps a diary, can be much wider than a simple desire for impartial recording of events and therefore one needs to consult other sources to verify the provided information.

According to the information available on the website, "absolutely all diaries present interest to the project" (prozhito.org), be it the diaries of famous personas or average citizens. Melnichenko says that diaries of average citizens are even more interesting as they rarely become available for the public eye but contain experiences and emotions anyone can relate to (Interview with Melnichenko 2017).

Organizationally Prozhito consists of a core team and a community of volunteers. The core team is built from people who are responsible for the overall concept of the project, the coordination of volunteers and laboratories, informational support, the development of specific projects, website development, support and editing (prozhito.org).

As the creation of an archive is a very time- and resource-consuming endeavor, Prozhito (being a non-commercial project) actively engages volunteers who collect, index, upload and tag diaries in the system. The core team defines tasks for the volunteers, which are communicated in authors' directories, where next to the name of the author's diary there is a mark signaling what kind of work could be performed by volunteers: text search, proof reading, editing or indexing (Fig. 21.3).

This means that volunteers can decide themselves which diary they want to work with depending on their personal interests and capabilities. The list of tasks for volunteers can be found on the Help page (Pomôs-in Russian). Reading this section reveals that while certain actions can be performed without any supervision (preparation of the text for being uploaded), some actions 


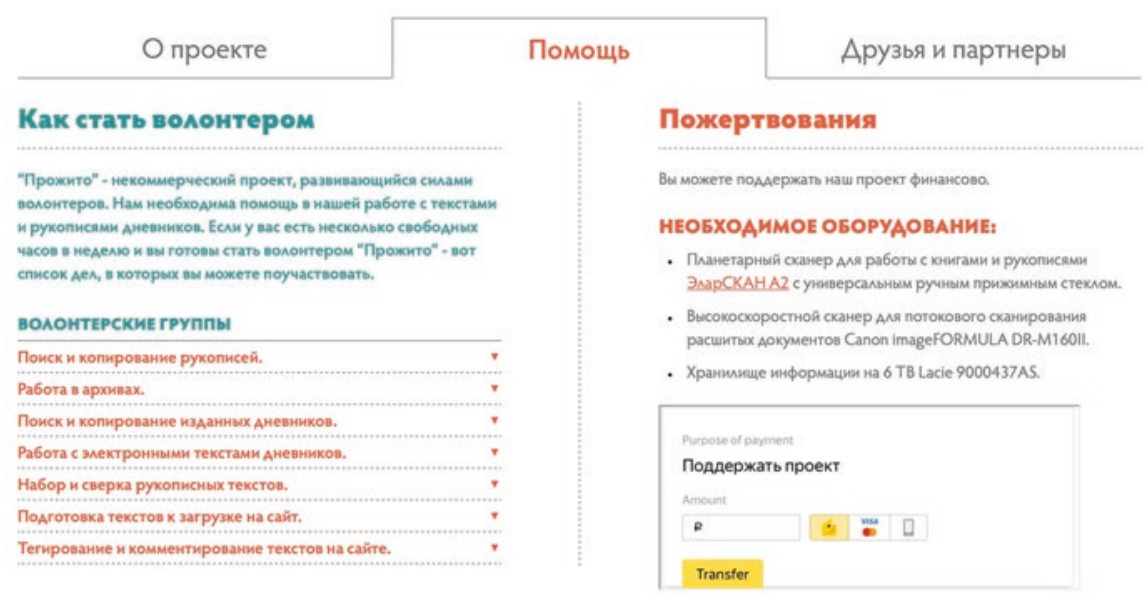

Fig. 21.3 Prozhito. The page Pomos' (Help), where volunteers can learn how they can contribute to the project

demand additional couching (such as proofreading and final editing) and require special access to the corpus of the texts (such as tagging).

Apart from collecting and making digital copies of diaries available online, Prozhito organizes special workshops called laboratories, where volunteers meet to transcribe and discuss manuscripts. These sessions usually last two or three hours, with curators providing historical context and some background information about the authors of the manuscripts. The goal of such labs is to work collaboratively on archival sources and by doing so sustain and educate the vibrant volunteer community. Usually such laboratories are organized at the GULAG (Glavnoe upravlenie lagerej i mest zaklûčeniâ, Main Administration of Camps) museum in Moscow. Starting from autumn 2019 regular laboratories are also organized at European University in St. Petersburg. Prozhito also arranges workshops in other cities in Russia, but on an irregular basis.

By 2019 the project developed new technological and organizational solutions to improve the user experience. Nevertheless, certain constraints of technological and legal nature set boundaries on what becomes available in this archive. Therefore, in the following sections the technological and legal constraints are reviewed to understand what users can do on the platform.

\subsection{Through a Glass Darkly: From Simple Affordance to Technological Constraints}

Prozhito has a number of simple and perceived affordances that become evident when a user opens the archive's home page. Prozhito's interface suggests that a user, by clicking on action buttons, can search the data for (1) names of the author or individuals mentioned in the entries; (2) date of the entry; (3) key 
words and tags. For example, if a user is interested in what happened on January 29,1917, he/she can type the date into the search field to see all entries that exist in the database with this date tag. The system also suggests different filters, such as gender, age and geographical location. This means that all diaries are indexed and tagged to be searchable in the database. This feature allows users to work both with the diaries of specific authors and with the whole corpus of texts uploaded in the system. This also means that the platform has some hidden affordances that could be used for scientific research, but the information on them is not available because the developers did not want to scare "average users with much too many scientific tools" (Melnichenko 2017) (Fig. 21.4).

However, as the project is still in the making and not all texts are tagged and indexed, there is an uncertainty regarding the search output. This is a considerable constraint that might prevent users from relying on algorithmic search in the corpus and force them to do the search manually.

The fragmentary nature of the search output is not the only constraint of the archive. Altered and incomplete documents are another issue of the archive. Digitally stored information entails a set of specific problems: depending on

\section{风 \\ Избранные цитаты}

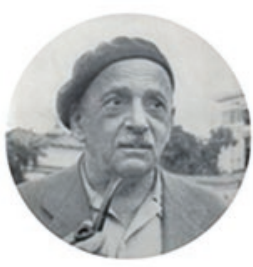

Павел Григорьевич Антокольский

5 апреля 1964 СуА был обставлен

гнусно. Наа Аверьми суаа висел плакат:

зАесь суАят тунеяАца. Письма

Чуковского и Маршака были

прочитаны вслух и не возымели никакого Аействия на судью и засеАателей, которые вели себя вызывающе грубо, орали на поАсУАимого БроАского. Невозможно понять, кому и зачем требуется это изАевательство наА труАом писателя, т.е. наА всей интемлигенцией. ...

\section{ПЕРЕЙТИ}

Fig. 21.4 Prozhito. A suggested page of a diary 
the protocols and the types of data storage, not all types of documents or not all parts of documents can be stored or can be stored without distortion (for more on corpora, see Chap. 19). Hence, there is "potential for documents to be altered electronically in their content, provenance or through migration to new storage systems" (Glotzer 2013). In the case of Prozhito, the original documents when uploaded into the system lose any type of imagery, such as diagrams and tables, photographs and drawings, as the archive is primarily a textual corpus. As no images can be saved as part of the original document, the diaries lose a part of their identity, making it also difficult for a researcher to learn about the people who have written them. Meanwhile, illustrations may tell a lot about the time the diaries were written, as well as function as codes that may contain some information the authors wanted to conceal from potential readers. Even though the images can be annotated in the commentaries (the same goes for codes), working with the digital copy limits the actions of a researcher and therefore limits interpretation. Curators promise that in the nearest future they will add original images of the diaries for the users to be able to get a sense of what the manuscripts look like and therefore narrow down the gap between the original document, its digital copy and the reader (Interview with Melnichenko 2017).

There is, however, a solution to this problem, which is anchored in a sequential affordance of the platform. The curators of the project remind users that there is always a possibility to either ask for an original copy from the curators or the owners of the diary or, if the original is stored in a state archive, consult the original there. The information about the original manuscript is usually located in the annotation to the entry and contains either a bibliographical note (if the diary is published) or the address where the original can be found.

Another constraint users experience on Prozhito is the inability to trace how and by whom documents were written and revised. The information about authorization of some parts of the text is marked with $\langle\ldots$. , but it does not allow tracing the history of the document, to see whether parts of a text were deleted or re-written, when exactly it happened and who did it. Such shortcomings undermine the validity of the sources and even historical narratives based upon them.

\subsection{Hidden AfFordances as a Result of Legal AND ETHICAl CONSTRAints}

Prozhito informs users about various legal and ethical constraints that may restrict access to the texts and define how diaries are published. The first constraint is a direct consequence of intellectual property rights as written in the Civil Code of the Russian Federation, which protects authors' rights and the rights of owners and publishers. To abide by the law and make digital versions of already published diaries available the curators need to get permission from the publishers: 
If we are lucky to find publishers, we ask for permission. If we do not have such possibility, we upload texts into the system, but keep them in such a "closed" regime that does not allow our users to read the texts, but only those entries that contain the names or the key words the users might be after. This means that these texts take part in the search, but the full access is not permitted. The search output is not yet available in the form of snippets, but in the form of the full diary entry. (Interview with Melnichenko 2017)

As it reads from the quote above, intellectual property right often determines the regime of visibility of uploaded diaries. Orphan texts, that is, texts that have no information about owners/authors, are only available in the citation regime allowed by the intellectual property legislation.

Melnichenko says that to enable the search function across as many documents as possible the curators strike agreements with publishers who allow digitization and indexing of their published books if Prozhito tells their readers where to buy these books. When it comes to unpublished manuscripts, the curators of the project try to get permissions from legal owners. If they cannot be found, diaries are uploaded to the database and remain there unless the owners show up and demand to take the diaries down. Such situations could be seen both as affordances and as constraints: the project curators dare to publish orphan texts and by doing so increase the number of texts participating in the search (an affordance); the possibility of removal, however, signals a constraint - a fact of censorship of an archival record.

Curators often collaborate with authors and owners to be able to publish diaries. Such practice often results in the editing of manuscripts. Melnichenko describes the process as follows:

We work in tight collaboration with the owners of manuscripts. After a text has been prepared for the upload it is given for a review to the owners, who have free hands to delete anything they consider sensitive. In other words, it means that we give the owners an opportunity to shorten the text. At the same time, we restrict users' access to those texts we consider too personal. These texts are still indexed and if a user types a key word and this word exists in this diary, the user can see the entry with this key word, but cannot read the whole diary. (Interview with Melnichenko 2017)

Melnichenko says that all diaries published after 1942 could be heavily edited due to the above-mentioned regulations, while all texts dated after December 31, 1999, are to be made invisible for the readers in order to protect the privacy of the individuals mentioned in the texts (Interview with Melnichenko 2017).

Another constraint that defines which diaries see the light has both legal and ethical dimensions. Diaries often contain information about third persons and therefore fall under personal data protection regulations. Some texts might even contain insults and ungrounded accusations, which means that they fall under the defamation law. Melnichenko says that sometimes curators 
themselves decide not to publish such texts due to personal reasons. He tells about a diary written by a woman full of frustration and hatred, which he felt reluctant to publish in order not to "let so much negative energy out into the world" (Interview with Melnichenko 2017).

The legal and ethical constraints mentioned above give the right to censor any information in the diary that can be deemed inappropriate or going against the current legislation of the Russian Federation. This means that the owners of the diaries and the curators of the project themselves can decide what information should be kept and what should be left out. These precautions taken by curators could also be seen as forced measures needed to safeguard the archive from the attacks of both Russian authorities and private individuals. As Prozhito makes information publicly available, it could be even considered a media source, which makes the platform vulnerable toward legislation that regulates mass media in Russia (The Law of the Russian Federation "On Mass Media" dated December 27, 1991, No. 2124-1). These regulations and laws guarding privacy of individuals and regulating sources of information can potentially hinder the construction of alternative historical narratives as information about perpetrators might never see the light, which might lead to the further silencing of the victims of the Soviet regime.

\subsection{Participation as a Complex AfFordance}

Digitization, that is, converting analogue documents into a digital format, is a time- and resource-consuming enterprise, which Prozhito resolves by using volunteer labor. Curators design tasks by taking into consideration people's different skills and abilities and even allow volunteers to withdraw at any time. In the language of affordances it means that the platform allows for multiple levels of engagement and disengagement and has a number of sequential and nested affordances. These multiple affordances are related to each other in the following manner: the discussions of diaries during Prozhito labs are possible because the Prozbito volunteers found these diaries in the archives and copied them; indexing and tagging of diaries is possible because the Prozhito volunteers transcribed these diaries. In both cases volunteers enable multiple interconnected actions and are the key actors in the process of creation and functioning of the platform.

Some of the activities performed by volunteers are possible in the digital environment (indexing, tagging, transcribing), while some, such as work in the archives, can only be performed offline. In any case, any activities the Prozhito volunteers are engaged in assume direct contact with personal diaries and with their authors. It has its social and cultural benefits. First, by working with private documents, one gets an opportunity to learn more about individual experiences and reflections about historical events and as a result build some sort of solidarity with and develop compassion toward the authors of the diaries. Second, this revelatory power of personal documents, that is, archive power, has an "important social function": 
It gives a new sense of life to many people, especially old ones. Before Prozhito, they thought that their lives and their diaries mattered very little. After they found out about Prozhito, they became very busy. Now they run around and organize editorial meetings with their grandchildren and children. (Interview with Melnichenko 2017)

This family engagement in editorial work is a form of collective remembering - a representative of an older generation passes on memories to a younger generation. A family member's private story becomes the subject of a collective experience; it allows for understanding historical events from a personal perspective.

At the same time narratives that emerge from personal documents can challenge historical master narratives. For the lab session it means that a diary has to be carefully chosen for its capacity to make a certain statement. Meanwhile, the curator's work implies giving the volunteers different means both to recognize master narratives that have to be challenged and to create new narratives based on the material in the diaries that they work with during the lab.

During one of such labs, volunteers worked with a diary of Chernevsky Oleg (Chinar, born 1921, the diary volume started June 21, 1938, and finished September 10, 1938), archived by Russian historical and human rights organization Memorial. A crucial element of this diary is the presence of several layers of coding. One of the layers is the actual code, a system of signs that is used to encode a secret text that is not supposed to be understood by others than the owner of the diary himself. Another layer of coding is a lingo that is used during a specific period of time, in this case the time of the Great Terror. Decoding these layers reveals a matrix of visible and invisible aspects of Soviet life: what was allowed and what was not allowed to say out loud.

When working with diaries, volunteers get a chance to see snapshots of everyday life in the form of everyday descriptions in the diaries (Herlitz and Westin 2018, 453). By doing so they experience so-called archival voyeurism, the desire to see what they were not meant to see (Baron 2014). What is important is that during such labs people engage into what could be called a collective archival voyeurism, a process of collective reading of a diary that unites a group of volunteers together when they communicate with each other trying to decipher what is written in a manuscript. During such labs, volunteers engage in a process of meaning-making by sharing each other's fragmentary historical knowledge and attempting to guess the emotional state of the author of a diary during the period of writing. This collective experience has a bonding effect: by sitting together around a table and working on different pieces of one diary, people start feeling a connection to each other because they all secretly spy on somebody's personal life.

Hence, the role of these labs is to introduce the public into an archive through embodied (typing, transcribing) and sensual (empathizing or/and sympathizing) experiences (Chakrabarty 2013, 457). The diaries used in the labs are of fragmentary character (only some parts of the diaries are used for 
work), which by nature can generate "a sense of the 'presence' of history" (Baron 2014, 12). The volunteers do not need to get the whole picture in its entirety presented to them. On the contrary, partial and incomplete information invites them to get engaged, to learn more. Being fragmentary, these diaries own a performative quality as they affect the volunteers and present a possibility for this audience to arise as active public through the interpretative act.

\subsection{Conclusion}

The aim of this chapter was to study Prozhito's potential for the production of historical knowledge in Russia. After having analyzed Prozhito's affordances several important aspects of the project have come forward.

First, the research has shown that affordance for democratic knowledge production is a nesting affordance, which is situated in several other simple and complex affordances, which in turn are sequential affordances. In practice it means that even though affordances exist independently of each other-for example, diaries are readable, indexable and searchable, they are also interdependant - diaries are readable because they are searchable and indexable. These simple affordances also allow for participatory practices, such as group discussions of Soviet history and collaborative work on the production of the Prozhito archive.

Second, sequences of these positive affordances emerge from a superordinate negative affordance- the impossibility to create the archive without the help of volunteers. As Prozhito does not have enough financial and technological resources, the work of collecting, preparing and editing texts is forced upon volunteers. This is a good example of how negative affordances of the environment, if handled creatively, condition positive changes and result in turn in the production of participatory infrastructures. Working on the creation of the archive gives people new meaning in life and ensures dialogue between different generations, family members and random people, who create their own networks by volunteering for Prozhito.

Third, archives like Prozbito in Russia indeed play an important political, social and cultural role by providing more democratic access to historical sources. By making alternative history narratives possible, archives mobilize communities for action, which results in independent learning and thinking.

By providing access to previously unavailable sources of information such archival initiatives also challenge state archives, which have always been central institutions for nation building and maintenance of political dominance through wielding power over the shape and direction of historical scholarship and collective memory.

However, being alternative public platforms for historical negotiations such archives become sites of conflict as they potentially might provide grounds for demanding justice. In the case of Prozhito, the curators put in place certain constraints to avoid potential conflicts of interests especially when it comes to 
publication of diaries written during the last seventy-five years. In other words, ethical and legal constraints condition what data has to see the light and determine the composition of archive that also might have some consequences. As the archive deals with documents of personal origin, which might contain data about third parties, crucial information has to wait for some time before it can be published, hence minimizing chances for justice. Meanwhile, as information about the removal of sensitive information is not provided, it also makes it difficult to search for evidence as no traces of such evidence remain. Therefore, when celebrating the evident democratic potential of such initiatives, one must remember that it is still an archive and it is still subjected to certain politics of invisibility conditioned by various constraints.

\section{REFERENCES}

Aghostino, D. 2016. Big Data, Time and the Archive. Symploke 24 (1-2): 435-445. Albrechtsen, H., Andersen, Hans H.K., Bodker, S., and Pejtersen, Annelise M. 2001. Affordances in Activity Theory and Cognitive Systems Engineering. Risø National Laboratory. http://www.risoe.dk/rispubl/SYS/syspdf/ris-r-1287.pdf.

Azoulay, A. 2012. Archive, Political Concepts: A Critical Lexicon. http://www.politicalconcepts.org/archive-ariella-azoulay/.

Baron, J. 2014. The Archive Effect: Found Footage and the Audiovisual Experience of History. London: Routledge.

Chakrabarty, D. 2013. Museums in Late Democracies. In The Visual Culture Reader, ed. Nicholas Mirzoeff, 3rd ed., 455-462. London: Routledge.

Derrida, J. 1995. Archive Fever: A Freudian Impression. Trans. Eric Prenowitz. Chicago and London: University of Chicago Press.

Fuchs, C. 2017. Social Media: A Critical Introduction. Los Angeles, London, New Delhi, Singapore, Washington DC, Melbourne: Sage.

Garde-Hansen, J., A. Hoskins, and A. Reading. 2009. Save as... Digital Memories. New York: Springer.

Gaver, W. 1991. Technology Affordances. In Proceedings of the ACM CHI 9l Human Factors in Computing Systems Conference, April 28-June 5, 1991, Scott P. Robertson, Gary M. Olson, and Judith S. Olson, eds., 79-84. New Orleans, Louisiana.

Gibson, J. 1979. The Ecological Approach to Visual Perception. New Jersey, USA: Lawrence Erlbaum Associates.

Glotzer, R. 2013. Archival Theory and Shaping of Educational History: Utilizing New Sources and Reinterpreting Traditional Ones. American Educational History Journal. https://www.thefreelibrary.com/Archival+theory+and+ the + shaping + of + educational + history $3 \mathrm{~A}+\mathrm{utilizing}+\mathrm{new}+\ldots$ a0370031204.

Herlitz, J., and J. Westin. 2018. Assembling Arosenius - Staging a Digital Archive. Museum Management and Curatorship 33 (5): 447-466. https://doi.org/10.108 0/09647775.2018.1496847.

Joyce, P. 1999. The Politics of the Liberal Archive. History of the Human Sciences 12 (2): 35-49.

Kak v raznyh stranah otkryvali dostup k arhivam KGB. 2018. 
Kakie dokumenty SSSR do sih por zasekrečeny. 2017.

Kalinina, E., and A. Kochergan. 2018. The Russian Revolution in Personal Diaries. Baltic Worlds 11 (1): 42-50.

Kallinikos, J., et al. 2013. The Ambivalent Ontology of Digital Artefacts. MIS Quarterly 27 (2): 357-370. https://doi.org/10.25300/MISQ/2013/37.2.02.

Komissiâ 2016 = Komissiâ po gostajne otkazalas' rassekrečivat' arhiv NKVD. 2016. RBC, January 19, 2016. https://www.rbc.ru/rbcfreenews/569ea0d29a794777 53125703.

Lapina-Kratasyuk, E., and M. Rubleva. 2018. Projects to Preserve Personal Memories: Digital Archives and Participatory Culture. Steps 4 (3-4): 147-163.

Manoff, M. 2004. Theories of the Archive from Across the Disciplines. Libraries and the Academy 4 (1): 9-25. https://doi.org/10.1353/pla.2004.0015.

Marton, A. 2010. The Transfigurability of Digital Objects. Artnodes, (10). http://artnodes.uoc.edu/ojs/index.php/artnodes/article/view/nlo-marton/ nl0-marton-eng.

Melnichenko, Mikhail. 2017. Interviewed by the author on March 21, 2017, in Moscow.

Morozov, E. 2011. The Net Delusion: The Dark Side of Internet Freedom. New York: Penguin Books Ltd.

Nisbet, E.C., E. Stoycheff, and K.E. Pearce. 2012. Internet Use and Democratic Demands: A Multinational, Multilevel Model of Internet Use and Citizen Attitudes About Democracy. Journal of Communication 62 (2): 249-265.

Norman, D. 1988. The Psychology of Everyday Things. New York: Basic Books.

Rambler 2017 = Kakie dokumenty SSSR do sih por zasekrečeny. 2017. Rambler.RU, August 29, 2017. https://news.rambler.ru/other/37760141-kakie-dokumentysssr-do-sih-por-zasekrecheny/.

Rød, E.G., and N.B. Weidmann. 2015. Empowering Activists or Autocrats? The Internet in Authoritarian Regimes. Journal of Peace Research 52 (3): 338-351. https://doi.org/10.1177/0022343314555782.

Rose, G. 2012. Visual Methodologies: An Introduction to Researching with Visual Materials. 3rd ed. London: Sage.

Slobodenyuk, I. 2019. Dumaû, èto stanet povsemestnoj praktikoj. Znak, March 13, 2019. https://www.znak.com/2019-03-13/gosarhiv_novosibirskoy_oblasti_ zakryl_dostup_k_fondam_kgb.

Stevenson, J. 2013. 'I Can Never Find Anything Among the Piles of Old Paper and General Rubbish': Edward Burra and his Archive. In All This Stuff! Archiving the Artist, ed. Judy Vaknin, Karyn Suckey, and Victoria Lane, 157-170. Faringdon: Libri.

Stoycheff, E., E.C. Nisbet, and D. Epstein. 2016. Differential Effects of CapitalEnhancing and Recreational Internet Use on Citizens' Demand for Democracy. Communication Research 10: 4345-4367. https://doi.org/10.1177/ 0093650216644645.

TASS 2018 = Kak v raznyh stranah otkryvali dostup k arhivam KGB. 2018. TASS.RU, December 20, 2018. https://tass.ru/info/5936863.

Turner, P. 2005. Affordance as Context. Interacting with Computers 17 (6): 787-800. Venyavkin, Ilya. 2017. Interviewed by the Author on September 10, 2017, online.

Wagman, J.B., S.E. Caputo, and T.A. Stoffregen. 2016. Hierarchical Nesting of Affordances in a Tool Use Task. Journal of Experimental Psychology: Human Perception and Performance 42 (10): 1627-1642. https://doi.org/10.1037/ xhp0000251. 
Open Access This chapter is licensed under the terms of the Creative Commons Attribution 4.0 International License (http://creativecommons.org/licenses/ by/4.0/), which permits use, sharing, adaptation, distribution and reproduction in any medium or format, as long as you give appropriate credit to the original author(s) and the source, provide a link to the Creative Commons licence and indicate if changes were made.

The images or other third party material in this chapter are included in the chapter's Creative Commons licence, unless indicated otherwise in a credit line to the material. If material is not included in the chapter's Creative Commons licence and your intended use is not permitted by statutory regulation or exceeds the permitted use, you will need to obtain permission directly from the copyright holder. 